\title{
STRATEGI MOMENTUM DAN STRATEGI VOLATILITAS MOMENTUM PADA SAHAM INDEKS LQ 45
}

\author{
Nanda Nanda \\ Universitas Andalas, Universitas Baiturrahmah \\ nandaismizal@gmail.com
}

Abstract

\begin{abstract}
This study looks at the return of the momentum strategy and the momentum volatility strategy of stocks listed on the LQ 45 Index for the 2010-2019 period. The method used in this research is the method of Jagedeesh and Titmant (1993) and Malin and Borhold (2011). Winning portfolios are formed by buying stocks with the best past return performance and selling stocks with past poor returns for a momentum strategy. Meanwhile, the loser portfolio is created by buying stocks with bad returns and selling stocks with good returns in the past. A momentum and volatility type is used in forming a portfolio of winners and losers for a momentum volatility strategy. Formations and observations were used 3,6 and 12 months-return momentum when the loser minus an optimistic winner. Significant momentum is determined by a one-sample t-test using SPSS 21. The study did not find returns from all momentum strategies statistically significant on stocks with LQ 45 Index for the 2010-2019 period. This result explains that the $L Q 45$ index is already in a weak form of efficient market condition. Investors cannot use this strategy to obtain excess returns when transacting on the $L Q 45$ index.
\end{abstract}

Keywords: loser portfolio; momentum strategy; momentum volatility strategy; volatility; winner portfolio.

\section{PENDAHULUAN}

Indeks LQ 45 merupakan salah satu indeks yang menjadi acuan utama investor dalam bertransaksi di Pasar Modal Indonesia. Karena, Indeks LQ 45 yang mengukur kinerja harga dari 45 saham yang memiliki likuiditas tinggi dan kapitalisasi pasar besar serta didukung oleh fundamental perusahaan yang baik. Evaluasi terhadap index LQ 45 dilakukan dalam 2 jenis, yaitu evaluasi mayor dilakukan enam bulan sekali yaitu pada Januari dan Juli, serta evaluasi minor pada April dan Oktober (idx.co.id, 2020). Likuiditas yang tinggi, indeks ini mengurangi risiko investor ketika bertransaksi di Pasar Modal. Kondisi ini menarik minat peneliti dan praktisi untuk melihat apakah bisa memeroleh excess return pada saham yang tergabung dalam indeks LQ 45 dengan menggunakan prediksi berdasarkan kinerja masa lalu atau analisis teknikal. Sehingga investor bisa memaksimalkan return dengan risiko yang lebih terjaga dari saham yang tergabung dalam LQ 45.

Prediksi return saham berdasarkan kinerja masa lalu telah diverifikasi menggunakan berbagai bentuk strategi dan periode. Kemampuan prediksi return masa depan dengan informasi masa lalu dinyatakan sebagai anomali dalam teori pasar efisien. Saat ini terdapat, dua anomali yang telah mapan dalam aset pricing yaitu momentum (Carhart, 1997) dan reversal (Chopra et al., 1992).. Anomali ini menantang teori pasar efisien bentuk lemah yang diperkenalkan oleh Fama (1970). Selama tiga dekade terakhir, efek momentum telah dianggap sebagai tantangan besar bagi teori pasar efisien, di mana dalam teori ini investor dapat memperoleh keuntungan dalam jangka panjang dengan berinvestasi pada saham dengan return yang tinggi pada periode waktu 3, 6 dan 12 bulan. Sedangkan menurut teori pasar yang efisien, investor tidak dapat memeroleh excess return di pasar modal. Sehingga pengujian strategi momentum ini juga sebagai salah satu indikator dalam melihat efisiensi suatu pasar (Fama,1970).

Strategi momentum pertama diperkenalkan oleh Jegadeesh \& Titman (1993) berdasarkan karakteristik return continuation, di mana saham dengan return yang tinggi di masa lalu akan mengulangi kinerja tersebut di masa depan dan sebaliknya saham dengan return rendah di masa lalu juga akan memiliki return rendah di masa depan. Strategi momentum ini dilaksanan dengan cara membeli saham yang memiliki kinerja bagus di masa lalu (saham winner) dan menjual saham dengan kinerja jelek di masa lalu (saham loser). sehingga membentuk portofolio winner yang berisikan saham-saham winner dan 
portofolio loser yang berisikan saham-saham loser. Jegadesh \& Titman (1993) sukses membuktikan strategi ini di pasar modal amerika untuk periode jangka menengah.

Kesuksesan strategi ini dipertimbangkan sebagai tantangan besar terhadap konsep pasar modal efisien bentuk lemah yang diperkenalkan oleh Fama (1970) di mana investor dengan menggunakan data masa lalu bisa memeroleh abnormal return. Tetapi dalam menentukan sumber dari excess return dari strategi momentum, penelitian sebelumnya memiliki banyak pertentangan. Sehingga menghasilkan berbagai variasi penjelasan momentum berdasarkan risiko dan perilaku namum belum ada penjelasan ini yang diterima secara luas (Lakonishok, Jegadeesh \& Chan, 1996).

Penelitian terbaru terkait strategi momentum menggunakan komponen spesisfik perusahaan memiliki kinerja lebih bagus dari momentum biasa(Grundy \& Martin, 2001; Gutierrez \& Pirinsky, 2007; dan Blitz et al., 2011). Grundy \& Martin (2001) menguji profit momentum berdasarkan komponen spesifik dari return yaitu dengan menggunakan alpha dari aset pricing. Gutierrez \& Pirinsky (2007) juga menilai profit momentum, menggunakan abnormal return dari firm-spesific yang ditentukan dari variasi return istimewa dari market model, momentum ini tetap berlanjut di tahun berikutnya, tetapi profit dari standar momentum berbalik dengan cepat di tahun tersebut. Ini sejalan dengan Blitz et al. (2011), momentum residual dari model Fama-French lebih menguntungkan dibandingkan dengan standar momentum. Blitz et al. (2013) juga menemukan kinerja dari sebuah strategi berdasarkan short-term reversal dari residual return saham adalah lebih tinggi dan memiliki volatilitas yang kurang dibandingkan dengan strategi short-term reversal konvensional. Strategi reversal residual tidak menampilkan paparan dari faktor dinamik sedangkan strategi reversal konvensional menampilkan. Studi ini menampilkan bahwa sumber prediktabilitas dalam kinerja masa lalu saham ada di bagian return tidak sistematis daripada bagian sistematis.

Barroso \& Santa-Clara (2015) menyatakan bahwa return momentum merupakan sebuah teka-teki karena memiliki korelasi negatif dengan faktor pasar dan nilai. Ketika diimplementasikan di pasar US, strategi momentum ini menghasilkan sebesar $1,75 \%$ return bulanan setelah disesuaikan dengan faktor risiko pada periode 1927-2011. Namun penelitian Moskowitz \& Daniel (2016) memerlihatkan bahwa return momentum sangat sering mengalami crash selama pasar reversal setelah terjadi fase bearish. Efek ini dipandang sebagai optionality efect dan beragumen strategi momentum selama pasar bearish seperti call option pada pasar, ketika pasar jatuh mengalami untung sedikit dan ketika pasar bullish mengalami rugi besar. Menariknya ketika menggunakan strategi manajemen risiko, memerlihatkan risiko crash bisa menjadi rendah, manajemen risiko ini menggunakan variasi equity market (Barroso \& Santa-Clara, 2015).

Sejalan dengan manajemen risiko atau metode skala risiko, strategi momentum dan volatilitas momentum mulai mendapatkan perhatian dalam literatur terbaru. Moreira \& Muir (2017) menemukan bahwa manajemen risiko bekerja baik dengan momentum, sementara Maio, Detzel \& Barroso (2016) mengemukan dengan menggunakan beta, menghasilkan return momentum sebanding dengan volatilitas momentum, sehingga volatilitas bisa digunakan dalam memerkuat return yang dihasilkan oleh strategi momentum. Penelitian yang mengabungkan strategi momentum dengan volatilitas juga dilakukan oleh Malin \& Bornholt (2011), di mana strategi momentum volatilitas menghasilkan return yang lebih besar dari strategi momentum biasa.

Penelitian mengenai strategi momentum dan kontarian di pasar modal Indonesia telah dilakukan sebelumnya, seperti penelitian Nugroho (2008) tentang strategi momentum di BEI; Dewi \& Samikadewi (2017) tentang return dari strategi momentu pada sektor keuangan; Saputro dan Badjra (2016) tentang strategi momentum pada sektor manufaktur; Wiastuti dan Maharani (2015) melihat reaksi berlebih pasar saham di BEI; Arfianto \& Maharani (2017) meneliti return momentum pada Indeks Kompas 100; Wibowo \& Mosii (2019) meneliti strategi momentum dan style momentum di pasar modal Indonesia; dan Nanda \&Adrianto (2019) meneliti strategi momentum pada indeks JII 30. Tetapi masih sedikit penelitian yang melakukan pengembangan strategi momentum di pasar modal Indonesia. Khususnya mengabungan volatilitas saham dan saham winner dalam pembentukan portofolio saham dalam strategi momentum. 
Melihat bahwa penelitian terkait pengembangan strategi momentum masih belum berkembang khususnya di pasar modal Indonesia, dan potensi pengunaan strategi ini juga belum di uji pada saham yang tergabung dalam Indeks LQ 45. Sehingga pengujian strategi momentum volatilitas serta membandingkan dengan strategi momentum biasa pada saham yang terdaftar pada indeks LQ 45 menjadi hal penting untuk diteliti. Tujuan penelitian ini untuk melihat strategi momentum volatilitas dan strategi momentum pasar modal Indonesia, khususnya pada indeks LQ 45. Selanjutnya penelitian ini juga melihat kedua strategi ini secara lebih luas, di mana penelitian Malin dan Borhold (2011) sebelumnya hanya membandingkan strategi momentum dengan volatilitas momentum yang menggunakan high volatilitas winner minus low volatilitas loser. Sedangkan dalam penelitian ini melihat lebih luas dari setiap kemungkinan hasil dua kali penyaringan dari portofolio. Selanjutnya melihat strategi mana yang lebih menguntung jika diterapkan pada saham LQ 45, apakah strategi momentum atau strategi momentum volatilitas. Serta melihat apakah indeks LQ 45 sudah berada pada pasar kondisi lemah atau belum sesuai teori pasar efisien.

\section{KAJIAN PUSTAKA DAN PENGEMBANGAN HIPOTESIS}

\section{Momentum}

Konsep efisien market hipotesis memiliki implikasi yang besar pada pendekatan investor dan trader di pasar modal. Mengenai ukuran EMH dalam konsep weak-form market efisien, return masa depan saham atau portofolio tidak dipengaruhi oleh return dari masa lalu. Dengan kata lain, tidak bisa mendapatkan tambahan return dengan dengan menggunakan trend masa lalu (Fama, 1970). Spekulasi ini diterima dengan baik sampai Jegadesh \& Titman (1993) memperkenalkan konsep anomali strategi momentum. JT berspekulasi bahwa pasar modal US tidak berada pada kondisi weak form setelah mereka meneliti strategi perdagangan di mana dengan menggunakan strategi ini investor memperoleh abnormal return. JT juga beragumen bahwa profitabilitas ini dengan gambaran risiko sistematis dari beta saham, sehingga ini berlawanan dengan hipotesis pasar sempurna yang dikemukan oleh Fama (1970).

Moskowitz \& Daniel (2016) menyatakan strategi momentum merupakan sebuah pertaruhan dalam memperoleh return di masa depan, karean ini menggunakan data masa lalu dalam dalam memilih saham yang akan dibeli. (Dhankar, 2017) menyatakan momentum merupakan tren keberlanjutan harga untuk jangka pendek. Strategi momentum pertama kali diperkenalkan oleh Jegadeesh \& Titman (1993). Strategi ini didasarkan pada price continiu, di mana saham dengan performance bagus di masa lalu akan memiliki kinerja bagus di masa depan dan sebaliknya. Sehingga strategi ini membentuk portofolio winner yang berisi saham dengan performace bagus dan portofolio loser yang berisikan saham dengan performance buruk. Return momentum dihitung dengan mengurangkan return portofolio winner dikurang portofolio loser (WML).

\section{Volatilitas Momentum}

Volatilitas adalah standar deviasi return suatu saham dalam periode tertentu dan merupakan ukuran ketidakpastian pergerakan harga saham di waktu yang akan datang. Volatilitas return saham menjelaskan risiko dari return saham tersebut. Semakin tinggi volatilitas semakin tinggi risiko dan sebaliknya semakin rendah volatilitas semakin rendah risiko. Estimasi volatilitas merupakan masalah penting dalam pengambilan keputusan dan penilaian risiko di pasar keuangan. Volatilitas sudah lama menjadi subjek yang menarik untuk pelaku pasar modal dan peneliti. Konsensus di sektor keuangan menyatakan volatilitas disebabkan oleh peningkatan kecepatan dan ketersedian informasi keuangan, investor institusional dan kemajuan pasar derivatif (Malin \& Bornholt, 2011). Malkiel \& Xu, (2003) menyatakan volatilitas masing-masing telah tumbuh dari waktu ke waktu. Tetapi tidak ada tren signifikan dalam volatilitas total pasar selama beberapa dekade.

Malin \& Bornholt (2011) meneliti apakah volatilitas bisa digunakan untuk meningkatkan profitabilitas dari standar momentum. Prosedur penyotiran dua kali digunakan untuk menghitung strategi momentum dengan volatilitas. Kemudian strategi momentum dengan volatilitas dibandingkan dengan strategi 
momentum biasa. Penelitian ini menemukan strategi momentum dengan volatilitas memiliki kinerja yang lebih baik dibandingkan dengan strategi momentum biasa.

\section{Hubungan antar variabel}

Strategi momentum secara umum diartikan merupakan sebuah fenomena di mana saham dengan performa bagus di masa lalu akan memiliki performa bagus di masa depan dan sebaliknya. Momentum merupakan tantangan terhadap teori risk and return dan pasar modal yang efisien (Leung, Fung, \& Yu, 2019). Barroso \& SantaClara (2015) menyatakan return momentum berkorelasi negatif dengan pasar dan faktor value.Penjelasan sumber momentum terbagi dalam dua kelompok: kelompok pertama, menyatakan bahwa profit dari strategi momentum merupakan kompensasi dari risiko. Sedangkan Leung et al. (2019) menyatakan momentum disebabkan oleh bias dari prilaku underreaction atau overreaction investor. Grundy \& Martin (2001); Barroso \& SantaClara (2015) momentum crash terjadi ketika market rebound setelah terjadi penurunan harga yang dalam. Disarankan pendekatan dengan menghitung risiko momentum dari varian return harian. Portofolio winner dan loser dibentuk berdasarkan varian. Hasil penelitian ini menemukan momentum berdasarkan risiko meningkatkan sharp ratio dan menurunkan risiko crash.

Moskowitz \& Daniel (2016) meneliti penyebab momentum crash dan apakah kondisi ini dapat diprediksi. Penelitian ini menemukan strategi momentum mengalami crash setelah pasar bearish, karena setelah pasar bearish portofolio loser menghasilkan return yang lebih besar. Moskowitz \& Daniel (2016) memerkenalkan strategi momentu dinamis, menemukan strategi ini memberikan return yang lebih besar, konstan serta volatilitas yang rendah dibandingkan dengan standar momentum.

H1: Terdapat return strategi momentum pada saham yang terdaftar dalam LQ 45.

Malin \& Bornholt (2011) memerkenalkan dua pemikiran tentang hubungan return saham dan volatilitas. pertama, return dan volatilitas memiliki korelasi positif, sehingga volatilitas yang tinggi akan memerkuat return dari strategi momentum dan sebaliknya. Strategi ini membeli saham winner dengan volatilitas yang tinggi dan menjual saham loser dengan volatilitas yang rendah. Pemikiran Kedua, berasal dari rekomendasi analisis saham dan profesional, rekomendasi ini bisa meningkatkan volatilitas saham karena saham tersebut akan semakin menarik investor. Pemikiran ini juga memprediksi portofolio winner dengan volatilitas yang tinggi akan memiliki kinerja yang lebih baik dibanding dengan portofolio winner umum yang digunakan dalam strategi momentum biasa.

H2: Terdapat return strategi volatilitas momentum pada saham yang terdaftar dalam LQ 45.

\section{METODE PENELITIAN}

Populasi yang digunakan dalam penelitian ini adalah semua saham yang terdaftar pada Indeks LQ 45 pada periode 2010-2019. Indeks ini dipilih karena merupakan kumpulan dari 45 saham terlikuid di pasar modal Indonesia dan merupakan rujukan utama investor di pasar modal Indonesia. Sedangkan periode 2010-2019 digunakan karena dalam periode ini telah terjadi pergerakan bearish dan bullish indeks, sehingga sangat tepat untuk menguji penerapan sebuah strategi prediksi pada indeks ini. Pemilihan sampel penelitian ini menggunakan purposive dan multhiphase sampling dengan kriteria sampel adalah: (1) Perusahaan harus tetap menjadi bagian indeks LQ 45 minimal dua kali periode pembentukan indeks; (2) Saham dikelompokan menjadi saham kelompok return tinngi, return rendah, return tinggi dengan volatilitas tinggi, return tinggi dengan volatilitas rendah, return rendah volatilitas tinggi dan return rendah volatilitas rendah; dan (3) memilih saham return tinggi untuk digabungkan ke dalam portofolio winner, saham return rendah digabung ke dalam portofolio loser, saham return tinggi volatilitas tinggi ke dalam portofolio high volatility winner, saham return tinggi volatilitas rendah ke dalam portofolio low volatility winner, saham return rendah volatilitas rendah ke dalam portofolio high volatility loser, dan saham return rendah volatilitas juga rendah digabungkan ke dalam portofolio low volatility loser. Berdasarkan kriteria yang sampel yang telah ditentukan, didapatkan sebanyak 77 perusahaan dari total saham Indeks LQ 45 selama periode penelitian. 
Jenis data yang digunakan pada penelitian ini adalah jenis data kuantitatif yaitu data perusahaan yang termasuk dalam indeks LQ 45. Penelitian ini menggunakan sumber data sekunder yaitu harga saham dan Indeks LQ 45. Data harga saham setiap bulan digunakan untuk menghitung return dan volatilitas saham, sedangkan data harga bulanan Indeks LQ 45 digunakan dalam menentukan return pasar. Data ini diperoleh dari situs yahoo.finance. Data saham pada Indeks LQ 45 diperoleh dari situs resmi BEI.

\section{Strategi Momentum}

Analisis strategi momentum mengikuti metode umum yang diperkenalkan oleh Jegadeesh \& Titman (1993). di mana data penelitian ini diolah sejalan dengan metode JT. Metode ini juga digunakan oleh ppenelitian sebelumnya seperti Jiang, Hua \& Chen, (2015), Yavuz \& Conrad, (2016), Dhankar, (2017), Nanda \& Adrianto (2019). Pada metode JT formasi (J) saham dibentuk dengan membagi-bagi saham berdasarkan peringkat return masa lalu, dan setelahnya dibentuk portofolio berdasarkan return masa lalu. Di mana portofolio yang berisikan saham dengan return yang tinggi akan menjadi portofolio winner. Sedangkan portofolio yang berisaikan saham dengan return rendah akan menjadi portofolio loser. Strategi momentum merupakan strategi dengan membeli portofolio winner dan menjual portofolio loser. Sedangkan sebaliknya strategi kontarian membeli saham loser dan menjual saham winner. Selanjutnya keuntungan strategi momentum dapat diketahui dengan melihat return dari hasil pembentukan portofolio ini setelah dilakukan holding selama periode yang telah ditetapkan. Return saham dihitung menggunakan formula (1):

$R_{j, t}=\frac{P_{j, t}-P_{j, t-1}}{P_{j, t-1}}$

Di mana:

$R_{j, t} \quad=$ Return saham bulanan

$P_{j, t} \quad=$ Harga saham pada bulan $\mathrm{t}$

$P_{j, t-1}=$ Harga saham bulan $\mathrm{t}-1$

Penelitian ini menggunakan periode bulanan 3, 6 dan 12 bulan, dalam membentuk portofolio (J) dan observasi (K). setelah itu lima saham dengan return tertinggi masuk ke dalam portofolio winner dan lima saham dengan return rendah masuk kedalam portofolio loser. Selanjutnya profit strategi momentum dihitung dengan portofolio saham winner dikurang portofolio saham loser (winner minus loser).

\section{Strategi Volatilitas Momentum}

Strategi volatilitas momentum dalam penelitian ini mengunakn dua penyaringan indeks untuk dua kondisi pasar emerging dan develop market. Penelitian ini menggunakan momentum untuk sortir pertama dan volatilitas untuk sortir kedua. Volatilitas yang digunakan adalah standar deviasi untuk periode enam bulam sejalan dengan Malin \& Bornholt (2011). Standar deviasi dihitung dengan rumus (2):

$$
\mathrm{S}=\sqrt{\frac{\sum_{i: 1}^{n}\left(x_{i}-\bar{x}\right)^{2}}{n-1}} .
$$

Di mana:

$\mathrm{S}:$ standar deviasi

$x_{i}$ : return saham I

$\bar{x}:$ rata-rata return saham

$\mathrm{n}$ : jumlah periode pengamatan. 
Strategi ini dibangun dengan membeli saham yang memiliki return yang tinggi serta menampilkan volatilitas tinggi selama enam bulan (High Volatility winner) dan menjual portofolio indeks yang memiliki return jelek serta volatilitas yang rendah selama enam bulan (Low volatilitas Loser). Return strategi momentum volatilitas dihitung dengan portofolio high volatility winner mimnus low volatility loser.

\section{Uji Beda}

Sejalan dengan Wibowo dan Mosii (2019); Dhankar (2017) uji T digunakan untuk melihat signifikan perbedaan return portofolio saham winner minus loser, high volatility winner minus high volatility loser, high volatility winner minus low volatility loser, low volatility winner minus high volatility loser dan low volatility winner minus low volatility loser.Pengujian signifikansi kinerja strategi momentum dilakukan dengan menggunakan SPSS 21 untuk menguji parametric one-sample t-test. Dengan formula (3) sebagai berikut :

$$
\mathrm{t}=\frac{X-u}{s / \sqrt{n}}
$$

Jika return portofolio saham winner minus loser, high volatility winner minus high volatility loser, high volatility winner minus low volatility loser, low volatility winner minus high volatility loser dan low volatility winner minus low volatility loser, signifikan positif besar dari nol, hipotesis H0 ditolatk. Dan sebaliknya jika return portofolio dari strategi trading sama dengan nol, hipotesis H0 diterima (Dhankar, 2017). Dengan rumusan hipotesis penelitian dalam uji one sample $t$ - test :

$\mathrm{H} 0=\mathrm{R}$ sama dengan nol.

$\mathrm{H} 1=\mathrm{R}$ tidak sama dengan nol

\section{HASIL DAN PEMBAHASAN}

Tabel 1 statistik deskriptif memerlihatkan average return dari strategi momentum dan strategi momentum volatilitas untuk periode pembentukan dan observasi 3, 6 dan 12 bulan.

Tabel 1.

STATISTIK DESKRIPTIF

\begin{tabular}{clrrrrr}
\hline Periode & \multicolumn{1}{c}{ Strategi } & N & Minimum & Maximum & \multicolumn{1}{c}{ Mean } & Std. Deviation \\
\hline \multirow{3}{*}{ 3 Bulan } & WML & 36 & -0.13 & 0.16 & 0.0084 & 0.06932 \\
& LVW-LVL & 36 & -0.17 & 0.17 & 0.004 & 0.08033 \\
& HVW-HVL & 36 & -0.29 & 0.23 & 0.0128 & 0.10952 \\
& HVW-LVL & 36 & -0.25 & 0.13 & 0.0003 & 0.08342 \\
& LVW-HVL & 36 & -0.15 & 0.27 & 0.0164 & 0.095 \\
\multirow{5}{*}{ Bulan } & WML & 18 & -0.23 & 0.25 & 0.0237 & 0.12419 \\
& LVW-LVL & 18 & -0.13 & 0.32 & 0.0327 & 0.10949 \\
& HVW-HVL & 18 & -0.36 & 0.34 & 0.0147 & 0.1687 \\
& HVW-LVL & 18 & -0.17 & 0.24 & 0.0089 & 0.11486 \\
& LVW-HVL & 18 & -0.31 & 0.41 & 0.0385 & 0.16976 \\
& WML & 9 & -0.48 & 0.25 & 0.0573 & 0.22451 \\
& WMLlan & 9 & -0.32 & 0.27 & 0.0374 & 0.17566 \\
& LVW-LVL & 9 & -0.63 & 0.39 & 0.0772 & 0.30097 \\
& HVW-HVL & 9 & -0.54 & 0.35 & 0.0475 & 0.28217 \\
& HVW-LVL & 9 & -0.42 & 0.48 & 0.0671 & 0.29539 \\
\hline
\end{tabular}

Sumber data diolah 
Hasil statistik deskriptif tabel 1, menunjukkan average return dari semua strategi momentum untuk semua periode 3 bulan nilainya adalah untuk strategi WML return 0,84\%, LVW-LVL return 0,4\%, HVW-HVL return 1,28\%, HVW-LVL 0,03\%, LVW-HVL 1,64\%. Berdasarkan statistik deskriptif pada periode pembentukan dan observasi tiga bulan ini terlihat bahwa strategi momentum secara keseluruhan menghasilkan return positif, dan strategi momentum volatilitas LVW-HVL menghasilkan return tertinggi dan diikuti oleh strategi HVW-HVL.

Average return dari semua strategi momentum untuk semua periode 6 bulan nilainya adalah untuk strategi WML return 0,0237 (2,37\%), LVW-LVL return 0,0327 (3,27\%), HVW-HVL return 0,0147 (1,47\%), HVW-LVL 0,0089 (0,89\%), LVW-HVL 0,0385 (3,85\%). Berdasarkan statistik deskriptif pada periode pembentukan dan observasi 6 bulan ini terlihat bahwa strategi momentum secara keseluruhan menghasilkan return positif, dan strategi momentum volatilitas LVW-HVL menghasilkan return tertinggi dan diikuti oleh strategi LVW-LVL.

Rata-rata return dari semua strategi momentum untuk semua periode 12 bulan nilainya adalah untuk strategi WML return 0,0573 (5,73\%), LVW-LVL return 0,0374 (3,74\%), HVW-HVL return 0,0772 (7,72\%), HVW-LVL 0,0475 (4,75\%), LVW-HVL 0,0671 (6,71\%). Berdasarkan statistik deskriptif pada periode pembentukan dan observasi 12 bulan menunjukkan strategi momentum secara keseluruhan menghasilkan return positif, dan strategi volatilitas momentum HVW-HVL menghasilkan return tertinggi dan diikuti oleh strategi LVW-HVL.

Hasil ini memerlihatkan bahwa strategi momentum dua kali pembentukan dengan menggunakan volalitas meningkatkan kinerja strategi momentum dalam menghasilkan return. Strategi momentum LVW-HVL untuk tiga periode pembentukan strategi menghasilkan return yang lebih baik dari strategi yang lain. Untuk melihat return dari strategi momentum signifikan atau tidak secara statistik, dilakukan uji parametrik one sample t-test. Hasil uji statistik dalam melihat signifikansi return dari masing-masing strategi momentum, uji parametrik one-sample t-test digunakan, hasil uji statistik pada tabel 2.

Tabel 2.

ONE-SAMPLE TEST

\begin{tabular}{|c|c|c|c|c|c|c|c|}
\hline \multirow{3}{*}{ Periode } & \multirow{3}{*}{ Strategi } & \multicolumn{6}{|c|}{ Test Value $=0$} \\
\hline & & \multirow[t]{2}{*}{$\mathbf{T}$} & \multirow[t]{2}{*}{ df } & \multirow[t]{2}{*}{$\begin{array}{l}\text { Sig. (2- } \\
\text { tailed) }\end{array}$} & \multirow[t]{2}{*}{$\begin{array}{c}\text { Mean } \\
\text { Difference }\end{array}$} & \multicolumn{2}{|c|}{$\begin{array}{l}\text { 95\% Confidence } \\
\text { Interval of the } \\
\text { Difference }\end{array}$} \\
\hline & & & & & & Lower & Upper \\
\hline \multirow{5}{*}{3 Bulan } & WML & 0.731 & 35 & 0.47 & 0.00844 & -0.015 & 0.0319 \\
\hline & LVW-LVL & 0.299 & 35 & 0.767 & 0.004 & -0.0232 & 0.0312 \\
\hline & HVW-HVL & 0.701 & 35 & 0.488 & 0.01279 & -0.0243 & 0.0498 \\
\hline & HVW-LVL & 0.025 & 35 & 0.98 & 0.00034 & -0.0279 & 0.0286 \\
\hline & LVW-HVL & 1.038 & 35 & 0.306 & 0.01644 & -0.0157 & 0.0486 \\
\hline \multirow{5}{*}{6 Bulan } & WML & 0.809 & 17 & 0.429 & 0.02369 & -0.0381 & 0.0854 \\
\hline & LVW-LVL & 1.266 & 17 & 0.223 & 0.03267 & -0.0218 & 0.0871 \\
\hline & HVW-HVL & 0.37 & 17 & 0.716 & 0.01471 & -0.0692 & 0.0986 \\
\hline & HVW-LVL & 0.33 & 17 & 0.746 & 0.00893 & -0.0482 & 0.066 \\
\hline & LVW-HVL & 0.961 & 17 & 0.35 & 0.03845 & -0.046 & 0.1229 \\
\hline \multirow{4}{*}{12 Bulan } & WML & 0.765 & 8 & 0.466 & 0.05728 & -0.1153 & 0.2299 \\
\hline & LVW-LVL & 0.638 & 8 & 0.541 & 0.03738 & -0.0976 & 0.1724 \\
\hline & HVW-HVL & 0.769 & 8 & 0.464 & 0.07719 & -0.1542 & 0.3085 \\
\hline & HVW-LVL & 0.505 & 8 & 0.627 & 0.04752 & -0.1694 & 0.2644 \\
\hline
\end{tabular}


Nanda Nanda. Strategi Momentum dan Strategi Volatilitas Momentum pada Saham Indeks LQ 45

\begin{tabular}{rllllll} 
LVW-HVL & 0.681 & 8 & 0.515 & 0.06705 & -0.16 & 0.2941 \\
\hline Sumber data diolah & & & & & &
\end{tabular}

Uji statistik one-sample t-test yang menguji return dari semua strategi momentum dengan membandingkan return dari semua strategi momentum dengan 0. Berdasarkan uji statistik one-sample t-test menunjukkan return semua strategi momentum dari semua periode memiliki nilai Sig. (2-tailed) berkisar dari 0,223 - 0,98, untuk semua strategi momentum dalam penelitian ini yang terdiri dari strategi WML (winner minus loser) sebesar, LVW-LVL (low volatility winner minus low volatility loser), HVW-HVL (high volatilitas winner minus high volatility loser), HVW-LVL (high volatility winner minus low volatility loser), LVW-HVL (low volatility winner minus high volatility loser). Karena nilai Sig. (2-tailed) lebih besar dari 0,05, sehingga H0 diterima dan H1 ditolak untuk semua strategi momentum yang di uji dalam riset ini. Sehingga return dari semua strategi momentum dalam semua periode waktu pembentukan dan observasi yang dilakukan pada indeks LQ 45 untuk periode waktu 2010-2019 tidak ada yang signifikan secara statistik.

\section{Pembahasan}

Temuan dari penelitian sejalan dengan penelitian Nanda \& Adrianto (2019) di mana return momentum tidak ditemukan pada indek JII, Leung et al. (2016), Chen et al. (2015) yang menemukan return momentum tidak signifikan di pasar saham China. Tanna \& Nnadi (2017) juga menemukan hasil return dari strategi momentum tidak signifikan untuk pasar saham Rusia. Selanjutnya Saputro \& Badjra, (2016) juga menemukan hasil yang sejalan. Rhee, Nakano, \& Chang, (2018) menunjukkan bahwa tidak terdapat return dari strategi momentum di pasar modal jepang.

Tetapi temuan dari penelitian ini tidak sejalan dengan Scrimgeour, Locke \& Gupta (2013), dan Brandao, Martins \& Martins (2016) menemukan terdapat return momentum yang signifikan di FSE. Bhootra (2018) menemukan terdapat return momentum pada pasar modal Amerika Serikat. Malin \& Bornhold (2011) yang menemukan return dari strategi momentum dan return dari strategi momentum volatilitas lebih besar dari strategi momentum biasa.

Tidak signifikannya return dari semua strategi momentum dan untuk semua periode pada saham yang yang tergabung dalam indek LQ 45. Ini membuktikan bahwa anomali momentum tidak terjadi pada indek LQ 45 meskipun straegi momentum sudah dimodifikasi dengan volatilitas return saham, sehingga ini semakin memperkuat bahwa indeks LQ 45 sudah berada di pasar dalam bentuk weak form strong, di mana dengan menggunakan data masa lalu abnormal return atau excess return tidak dapat diperoleh. Sehingga strategi ini tidak bisa diterapkan oleh investor dalam meningkatkan keuntungan ketika bertransaksi pada saham yang terdaftar di indeks LQ 45.

Kondisi ini bisa disebabkan karena indeks LQ 45 merupakan kumpulan 45 saham terlikuid di Pasar Modal dan disesuaikan setiap enam bulan sekali. likuiditas yang tinggi mengurangi risiko saham, tidak signifikannya return dari semua strategi momentum pada saham yang terdaftar dalam indeks LQ 45 juga mendukung pandangan penelitian sebelumnya bahwa strategi momentum merupakan kompensasi dari risiko (Du, 2012).

Hasil ini dari pengujian strategi ini, menjelaskan bahwa strategi momentum dan strategi momentum volatilitas tidak bisa dijadikan acuan oleh investor yang ingin memperoleh excess return ketika bertransaksi di pasar modal khususnya pada saham LQ 45. Temuan ini juga menerangkan bahwa saham yang tergabung dalam indeks LQ 45 sudah berada pada kondisi pasar bentuk lemah dalam teori pasar efisien. Karena excess return tidak dapat diperoleh dengan mengeksplorasi informasi harga masa lalu. Hasil ini juga menerangkan ke pihak regulator pasar modal, bahwa pasar modal Indonesia sudah mengarah ke pasar modal yang efisien, di mana kondisi pasar efisien merupakan tujuan dari setiap pasar modal pada setiap negara.

\section{KESIMPULAN}


Berdasarkan analisis serta pembahasan yang telah ditampilkan sebelumnya mengenai return dari strategi momentum dengan menggunakan return masa lalu dan menggunakan volatilitas serta return masa lalu dalam pembentukan portofolio winner dan loser, pada saham yang tergabung dalam indek LQ 45. indeks LQ 45 merupakan kumpulan 45 saham-saham dengan likuiditas terbalik di Pasar Modal Indonesia yang disesuaikan setiap enam bulan sekali.

Metode yang digunakan untuk menentukan strategi momentum harga menggunakan metode Jagadeesh dan Titmant (1993). Sedangkan metode yang digunakan dalam menentukan strategi momentum volatilitas mengukuti Malin dan Bornhold (2011). Di mana untuk strategi momentum saham dengan return tertinggi akan dimasukan ke dalam portofolio winner sedangkan saham yang memiliki return terendah akan dimasukan kedalam portofolio loser. Untuk strategi momentum volatilitas menggunakan dua kali sortir dalam membentuk portofolio, di mana mengikuti pola strategi momentum harga untuk sortir pertama dan menggunakan volatilitas dalam sortir kedua.

Periode 3, 6 dan 12 bulan digunakan dalam membentuk formasi dan observasi pada penelitian ini. WML positif memperlihatkan adanya return momentum dan sebaliknya WML negatif mengidentifikasi adanya return kontarian. Karena dalam penelitian ini strategi momentum terdiri dari strategi momentum harga dan momentum volatilitas sehingga WML bervariasi sesuai dengan straegi momentum yang diwakilinya. Hasil penelitian ini tidak menemukan adanya return yang signifikan dari semua strategi momentum yang dilakukan dalam penelitian ini.

Berdasarkan hasil penelitian ini maka rekomendasi bagi penelitian selanjutnya: untuk mengeskplorasi strategi momentum secara lebih mendalam bisa pada pengujian objek yang lebih luas, sumber excess return strategi momentum dan mengembangkan modifikasi serta kombinasi dari strategi ini. Karena penelitian ini, baru sebatas mengembangan dan mengombinasikan strategi ini dengan volatilitas dan baru sebatas indeks LQ 45.

\section{DAFTAR PUSTAKA}

Arfianto, D., \& Maharani, E. (2017). Analisis Pengaruh Momentum , Trading Volume dan Size Terhadap Disposition Effect dan Return Aplikasi Cross Sectional Regresion. Diponegoro Journal Of Management. 6 (1), 139-153

Barroso, P., \& Santa-Clara, P. (2015). Momentum has its Moments. Journal of Financial Economic, $116(1), 111-120$.

Blitz, D., Huij, J., \& Martens, M. (2011). Residual Momentum. Journal of Empirical Finance. 18, (3), 506-521

Bhootra, A.(2018), "Gross Profitability and Momentum" Managerial Finance, 44(8), 9921011. https://doi.org/10.1108/MF-11-2017-0444

Carhart, M. M. (1997). On persistence in Mutual Fund Performance. The Journal of finance, 52(1), 5782.

Chopra, N., Lakonishok, J., \& Ritter, J. (1992). Measuring Abnormal Performance: Do Stocks Overreact? Journal of Financial Economics, 31(2), 235-268.

Dewi, R. M., \& Sasmikadewi, A. I. (2017). Perbandingan Kinerja Portofolio Saham Winner - Loser Berdasarkan Strategi Investasi Momentum. E-Jurnal Manajemen Unud. 6(2), 857-888

Dhankar, S, R. (2017). Momentum Anomaly: Evidence From The Indian Stock Market. Journal of Advances in Management Research. 14 (1), 3-22 
Nanda Nanda. Strategi Momentum dan Strategi Volatilitas Momentum pada Saham Indeks LQ 45

Du, Ding. (2012). Momentum and Behavioral Finance. Managerial Finance. 38(4). 364 - 379

Fama, E. F. (1970). Efficient Capital Markets: A Review of Theory and Empirical Work. The Journal of Finance, 25(2), 383-417.

Fama, F. E., \& French, R. K. (1993). Common Risk Factor in The Returns on Stock and Bonds. Journal of Financial Economics. 33, 3-56.

Gutierrez, R. C., \& Prinsky, C. A. (2007). Momentum, Reversal, and The Trading Behaviors of Institutions. Journal of Financial Markets $10, \quad 48-75$. https://doi.org/10.1016/j.finmar.2006.09.002

Grundi., \& Martin, S. J. (2001). Understanding The Nature of The Risk and The Source of The Reward to Momentum Investing. The Review Of Financial Studies. 14(1), 29-78.

PT Bursa Efek Indonesia.2021. Indeks. (https://www.idx.co.id/produk/indeks, diakses pada 35 Maret 2021)

Jegadeesh, N., \& Titman, S. (1993). Returns to Buying Winners and Selling Losers: Implications for Stock Market Efficiency. The Journal of Finance. 48(1), 65-91.

Jiang, Y., Hua, X., \& Chen, Q. (2015). Contrarian strategy and herding behaviour in the Chinese stock market. The European Journal ofFinance. 24(16), 1552-1568

Lakonishok, J., Jegadeesh, N., \& Chan, L. K. C. (1996). Momentum Strategies. Journal of Finance, 51(5),1681-1713. https://doi.org/10.1111/j.1540-6261.1996.tb05222.x

Leung, K, W., Fung, g., \& Yu, L. (2019). Momentum or Contrarian Trading Strategy: Which one works Better in the Chinese Stock Market. International Review of Economics and Finance. 62(c), 87105 .

Maio, P., Detzel, A., \& Barroso, P. (2016). Managing the Risk of The Low-risk Anomaly. SSRN Electronic Journal. DOI:10.2139/ssrn.2876450

Malin, M., \& Bornholt, G. (2011). Using Volatility to Enhance Momentum Strategies. JASSA The Finsia Journal Of Applied Finance. 2, 16-21

Malkiel, G, B., \& Xu, y. (2003). Investigating the Behavior of Idiosyncratic Volatility. The Journal of Business. 76 (4), 613-645

Moreira, A., \& Muir, T. (2017). Volatility-Managed Portfolios. The Journal of Finance. 72 (4), 16111643

Moskowitz, J. T., \& Daniel, K. (2016). Momentum Crash. Journal of Financial Economic, 122, 221 247.

Nanda., \& Adrianto. (2019). Abnormal Return Momentum pada Saham Syariah di Jakarta Islamic Indeks. Jurnal Ilmiah Mahasiswa Ekonomi Manajemen. 4 (4), 773-785.

Nugroho, Y. B. (2008). Profitabilitas Strategi Momentum di Bursa Efek Indonesia (Periode Januari 2003 - Desember 2007). Jurnal Siasat Bisnis. 12(3), 175 - 186.

Rhee, G. H., Nakano, S., \& Chang. (2018). Residual Momentum in Japan. Journal of Empirical Finance 45, 283-299. 
Saputro, N., \& Badjra, B. (2016). Kinerja Portofolio Saham Berdasarkan Strategi Investasi Momentum pada Industri Manufaktur. E-Jurnal Manajemen Unud, 5(1), 623-649

Scrimgeor, F., Locke, S., \& Gupta, K. (2013). Profitability of Momentum Returns Under Alternative Approaches. International Journal of Managerial Finance, 9(3), 219- 246.

Tanna, S., \& Nnadi, M. (2017). Accounting analyses of momentum and contrarian strategies in emerging markets. Asia-Pacific Journal of Accounting \& Economics.26 (4), 457-477. https://doi.org/10.1080/16081625.2017.1284596

Wiastuti, S, R., \& Maharani, S. (2015). Fenomena Market Overreaction di Bursa Efek Indonesia. Management Analisys Journal.4 (1), 30-38.

Wibowo, S, S., \& Mosii, L, R. (2019). The Profitability of Momentum Strategies: A Study Of Indonesian Stock Exchange. Indonesian Capital Market Review.11,15-29.

Yavuz., \& Conrad. (2016). Momentum and Reversal: Does What Goes Up Always Come Down? Review of Finance, 21(2), 555-581. 10.1093/rof/rfw006 